\title{
Classification of the "Rhodochrous" Complex and Allied Taxa Based upon Deoxyribonucleic Acid Reassociation
}

\author{
M. MORDARSKI, M. GOODFEllow, K. SZYBA, G. PULVERER, and A. TKACZ \\ Department of Biosynthesis, Institute of Immunology and Experimental Therapy, Wroctaw, Poland; \\ Department of Microbiology, The Medical School, The University, Newcastle upon Tyne NE1 7RU, \\ United Kingdom; and Institute of Hygiene, University of Cologne, Cologne, \\ Federal Republic of Germany
}

The degree of binding was determined between deoxyribonucleic acid (DNA) preparations from nocardiae and "rhodochrous" strains and uracil-labeled DNA from three reference strains, Nocardia asteroides N668 and rhodochrous strains $\mathrm{N} 11$ and N54. In all cases, good congruence was found between the DNA reassociation data and that from numerical phenetic studies. Only a small degree of nucleotide sequence homology was found between the $N$. asteroides reference system and the other taxa studied, and there was evidence that $N$. asteroides is genetically heterogeneous. The moles percent guanine plus cytosine for the rhodochrous strains was within the range 58 to 67 ; the corresponding range for nocardiae was 64 to $68 \mathrm{~mol} \%$.

The confused and tortuous taxonomic history of bacteria variously known as "Mycobacterium" rhodochrous, the "rhodochrous" complex, and the "rhodochrous" taxon was reviewed by Bousfield and Goodfellow (5), who concluded that these organisms form a recognisable taxon equivalent in rank to the genera Corynebacterium, Nocardia, and Mycobacterium. The internal structure of the rhodochrous complex is still obscure, but the results of chemical $(2,3,17)$, numerical phenetic $(17,39)$, deoxyribonucleic acid (DNA) reassociation (10), genetic recombination (1), and serological (24) studies show that subgroups exist.

The heterogeneity of the rhodochrous complex is most clearly seen in numerical phenetic studies in which two or more homogeneous phena have been recognised $(6,16,17,22,35)$. However, since few strains are common to all of these investigations, it is difficult to determine whether or not, and to what extent, the phena overlap. In an extensive numerical taxonomic study, Goodfellow and Alderson (J. Gen. Microbiol., in press) divided 150 representative rhodochrous strains into 10 homogeneous subclusters (1A through $1 \mathrm{~J}$ ). Subcluster $1 \mathrm{~A}$ was equated with $N$. rubra (6), Gordona rhodochroa (38), and phenon 1a (17); subclusters $1 \mathrm{~B}$ and $1 \mathrm{E}$ were equated with phena $14 \mathrm{~B}$ and $14 \mathrm{~A}(16)$, respectively; subcluster $1 \mathrm{D}$ was equated with $N$. pellegrino (28); subclusters $1 \mathrm{~F}$ and $1 \mathrm{G}$ were equated with phena $1 \mathrm{c}$ and $1 \mathrm{~b}(17)$, respectively; subcluster $1 \mathrm{H}$ was equated with $N$. erythropolis (6) and phena 14D (16) and F3 (22); and subcluster $1 \mathrm{~J}$ was equated with bacteria given the trivial name "Lspi" (large, spored, pink, irregular) (15). Subcluster $1 \mathrm{C}$ can be subdivided fur- ther and contains strains of $G$. bronchialis, $G$. rubra, and G. terrae (37).

Good congruence has been observed between nucleotide sequence homology and numerical phenetic data in a number of genera including actinomycete taxa $(13,19,34)$. In most cases, taxospecies share at least $70 \%$ DNA homology, and lower binding values are considered to reflect significant genetic divergence (12). In an earlier DNA reassociation study, Mordarski et al. (29) found that representatives of $G$. bronchialis, G. rubra, G. terrae, N. pellegrino (28), and phenon 1a (17) formed DNAhomology groups. In view of these encouraging results, we have extended our DNA reassociation assays on nocardioform bacteria and in this study show the degree of binding between DNA preparations from nocardiae and rhodochrous strains and uracil-labeled DNA from three reference systems including the type strain of "Mycobacterium" rhodochrous.

\section{MATERIALS AND METHODS}

Test strains and growth conditions. Details of strains and their sources are given in Table 1. All cultures were maintained routinely on yeast extract agar at room temperature.

For DNA extraction, organisms were grown in shake cultures on a reciprocal shaker (160 strokes per min) for 30 to $40 \mathrm{~h}$ at $37^{\circ} \mathrm{C}$ in modified Sautons medium (27) or in peptone-yeast extract broth (7). Cultures were checked for purity, harvested by centrifugation, washed in $0.15 \mathrm{M}$ saline- $0.1 \mathrm{M}$ ethylenediaminetetraacetate $(\mathrm{pH} 8.0)$, and stored at $-20^{\circ} \mathrm{C}$.

Extraction of DNA. DNA was extracted from harvested bacteria by using the materials and methods described previously (29). All DNA preparations 
TABLE 1. Designation, sources, and DNA base composition of test strains ${ }^{a}$

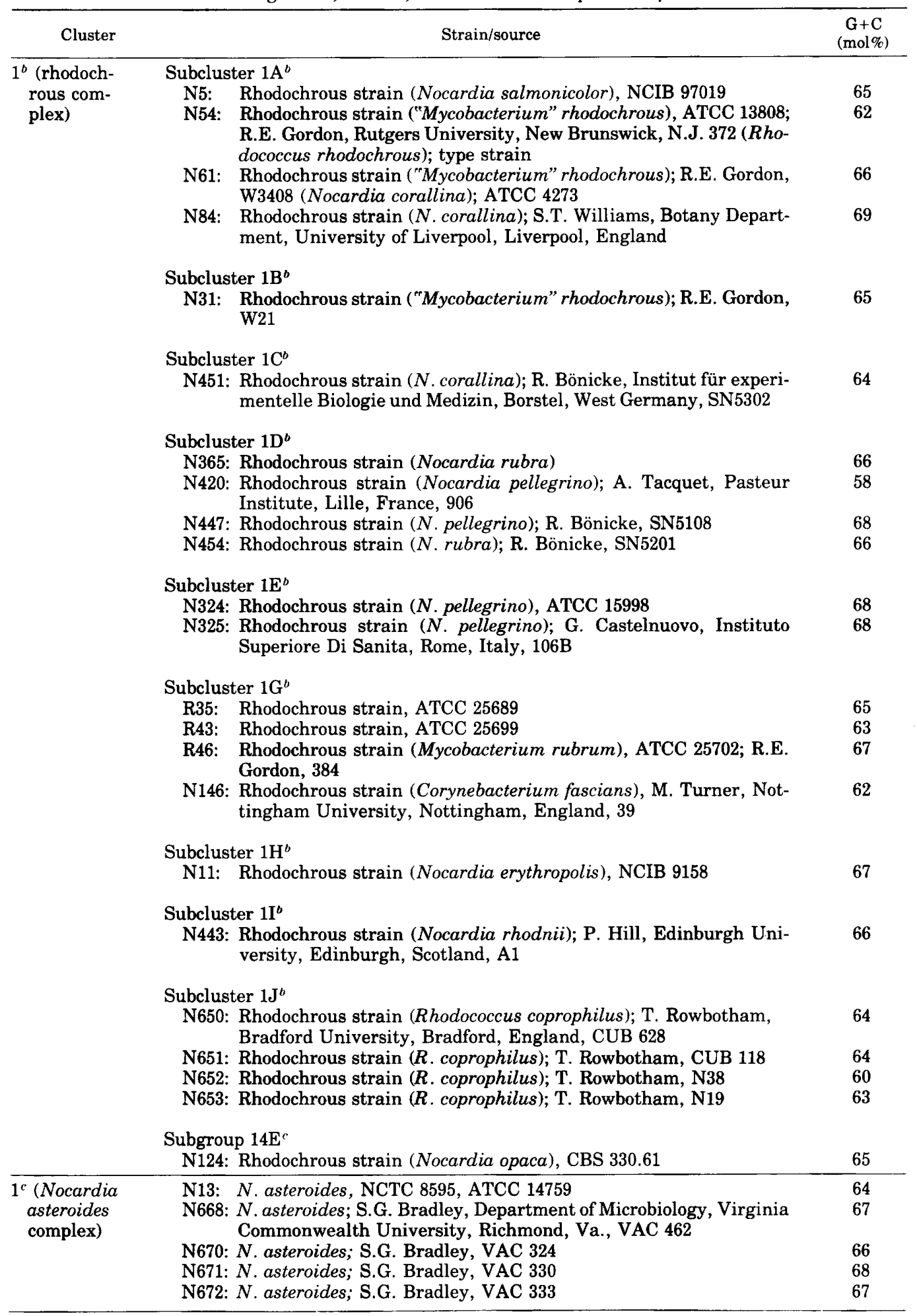


TABLE 1-Continued

\begin{tabular}{|c|c|c|}
\hline Cluster & Strain/source & $\begin{array}{c}\mathbf{G}+\mathbf{C} \\
(\mathrm{mol} \%)\end{array}$ \\
\hline & $\begin{array}{l}\text { N675: Nocardia carnea; R.E. Gordon } 3419 ; \text { ATCC } 6847 \\
\text { N676: N. carnea; R.E. Gordon, 3419; ATCC } 6847 \\
\text { N537: Nocardia salmonicida, NRRL B-2778; type strain } \\
\text { N680: Nocardia transvalensis; R.E. Gordon, IMRU 3246; NCTC 2392; } \\
\text { ATCC } 6865\end{array}$ & $\begin{array}{l}68 \\
64 \\
66 \\
67\end{array}$ \\
\hline $\begin{array}{c}2^{c}(\text { Nocardia } \\
\text { caviae })\end{array}$ & $\begin{array}{l}\text { N36: N. caviae, NCTC 1934; ATCC 14629; type strain } \\
\text { N231: } N \text {. caviae; R. Olds, Pathology Department, Cambridge Univer- } \\
\text { sity, Cambridge, England, CN749 } \\
\text { N313: N. caviae; F. Mariat, Institut Pasteur, Paris, } 751 \\
\text { N563: } N . \text { caviae; D. Frey, The Royal North Shore Hospital of Sydney, St. } \\
\text { Leonards, N.S.W., Australia, } 1912\end{array}$ & $\begin{array}{l}67 \\
67 \\
66 \\
66\end{array}$ \\
\hline $\begin{array}{c}5^{c}(\text { Nocardia } \\
\text { brasiliensis })\end{array}$ & N318: $N$. brasiliensis, ATCC 19296; type strain & 67 \\
\hline $\begin{array}{l}7^{c} \text { (Actino- } \\
\text { madura } \\
\text { madurae) }\end{array}$ & $\begin{array}{l}\text { N306: A. madurae; F. Mariat, } 767 \\
\text { Strain not included in the numerical analyses } \\
\text { N667: Nocardia amarae; M. Lechevalier, IMRU W3960; ATCC 27808; } \\
\text { type strain }\end{array}$ & 65 \\
\hline
\end{tabular}

a ATCC, American Type Culture Collection, Rockville, Md.; CBS, Centralbureau voor Schimmelcultures, Baarn, The Netherlands; NCIB, National Collection of Industrial Bacteria, Aberdeen, Scotland; NCTC, National Collection of Type Cultures, London, England; NRRL, Northern Utilization Research and Development Division, U.S. Department of Agriculture, Peoria, Ill.

Phena recovered by Goodfellow and Alderson (in press).

c Phena recovered by Goodfellow (16).

used for reassociation showed $E_{260} / E_{280}>1.9$ and $E_{225} / E_{230}>2.1$, and gave a negative Lowry test for proteins and a negative concanavaline $\mathrm{A}$ diffusion test for carbohydrate contamination. Reaction with orcinol for contaminating RNA indicated less than $5 \%$ ribonucleic acid (RNA). The purified DNA was stored at $5^{\circ} \mathrm{C}$ in $0.1 \times \mathrm{SSC}(\mathrm{SSC}=0.15 \mathrm{M} \mathrm{NaCl}$ $0.015 \mathrm{M}$ trisodium citrate) containing a few drops of chloroform.

Preparation of radioactive DNA for homology studies. $\left[2-{ }^{14} \mathrm{C}\right]$ uracil (Nuclear Research Institute, Swierk, Poland; specific activity, 9.6 to $12.3 \mathrm{mCi} /$ mol) was added to inoculated media to give a final concentration of $1 \mu \mathrm{gCi} / \mathrm{ml}$. Labelled organisms were centrifuged and the DNA was extracted and purified as described previously (29).

Labelled reference DNA was prepared from three strains: $N$. asteroides $\mathrm{N} 668$ and rhodochrous strains N11 (NCIB 9158) and N54 (ATCC 13808). The specific activities of the reference DNA preparations are shown in Table 2.

Analysis of base compositions. The moles percent guanine plus cytosine content was determined by the method of Huang and Rosenberg (21).

Fixation of denatured, high-molecular-weight DNA on membrane filters and DNA:DNA pairing. The relationships between the test strains were established by determining the extent to which immobilised single-stranded DNA bound labelled reference DNA in solution. The reassociation was performed on nitrocellulose membranes (Sartorius SM1140 ) in $2 \times$ SSC solution plus $30 \%$ (vol/vol) dimethyl sulphoxide for $18 \mathrm{~h}$ at $65^{\circ} \mathrm{C}$. The methods used were described in detail elsewhere (29).

Thermal stability of DNA:DNA duplexes. The thermal stability of duplexes formed between filterbound DNA and the reference DNA preparations was determined from the $T_{m(e)}$ values. $\left[T_{m(e)}\right.$ is the temperature at which half of the reassociated reference DNA becomes dissociated and eluted from the test DNA bound to the filter.] The midpoint of the thermal elution, $\Delta T_{m(e)}$, was found by subtracting the $T_{m(e)}$ of hybrids of the heterologous system from the $T_{m(e)}$ of homologous hybrids $(30)$.

After pairing was completed, the filters were dried and then eluted with $0.1 \times$ SSC solution at temperature increments of $5^{\circ} \mathrm{C}$ over the range 70 to $100^{\circ} \mathrm{C}$. The radioactive samples were assayed in the scintillation fluid of Bray (11).

\section{RESULTS}

DNA base compositions. The moles percent guanine plus cytosine $(\mathrm{G}+\mathrm{C})$ for the rhodochrous strains was 58 to 67 ; the corresponding range for the Nocardia strains was 64 to 68 mol\% (Table 1).

DNA:DNA pairing. The DNA preparations from all of the subcluster 1A strains bound significant amounts of reference DNA from the rhodochrous type strain (N54) but showed little affinity with that from rhodochrous strain N11 and $N$. asteroides N668. Rhodochrous strains N31 and N454, from subclusters $1 B$ and 1D, respectively, exhibited a high degree of homology with the reference DNA from rhodochrous strain N54; a much smaller degree of nucleotide sequence homology was found between this ref- 
TABLE 2. Reassociation of DNA samples from Nocardia, Actinomadura, and rhodochrous strains with the DNA from reference strains Nocardia asteroides N668 and rhodochrous strains N11 and N54"

\begin{tabular}{|c|c|c|c|c|c|c|c|c|c|}
\hline \multirow[b]{3}{*}{ DNA source } & \multicolumn{9}{|c|}{ Labelled DNA source } \\
\hline & \multicolumn{3}{|c|}{ Rhodochrous strain N11 } & \multicolumn{3}{|c|}{$\begin{array}{l}\text { Rhodochrous strain } \\
\text { N54 }\end{array}$} & \multicolumn{3}{|c|}{ Nocardia asteroides N668 } \\
\hline & $\begin{array}{c}\text { Rela- } \\
\text { tive } \\
\text { DNA } \\
\text { bound } \\
(\%)\end{array}$ & $\begin{array}{l} \pm \text { Stan- } \\
\text { dard } \\
\text { error }\end{array}$ & $\begin{array}{l}\Delta T_{m(e)} \\
\left({ }^{\circ} \mathrm{C}\right)\end{array}$ & $\begin{array}{c}\text { Rela- } \\
\text { tive } \\
\text { DNA } \\
\text { bound } \\
(\%)\end{array}$ & $\begin{array}{c} \pm \\
\text { Stan- } \\
\text { dard } \\
\text { error }\end{array}$ & $\begin{array}{l}\Delta T_{m(e)} \\
\left({ }^{\circ} \mathrm{C}\right)\end{array}$ & $\begin{array}{c}\text { Rela- } \\
\text { tive } \\
\text { DNA } \\
\text { bound } \\
(\%)\end{array}$ & $\begin{array}{l} \pm \text { Stan- } \\
\text { dard } \\
\text { error }\end{array}$ & $\begin{array}{l}\Delta T_{m(e)} \\
\left({ }^{\circ} \mathrm{C}\right)\end{array}$ \\
\hline Subcluster 1A & & & & & & & & & \\
\hline N5: Rhodochrous strain & 21 & 1 & & 83 & 2 & 5 & 19 & 2 & \\
\hline N54: Rhodochrous strain & 16 & 1 & & 100 & & & 18 & 2 & \\
\hline N61: Rhodochrous strain & 18 & 1 & & 85 & 4 & 1 & 19 & 1 & \\
\hline N84: Rhodochrous strain & 13 & $<1$ & & 96 & 6 & 1 & 15 & 1 & \\
\hline \multicolumn{10}{|l|}{ Subcluster 1B } \\
\hline N31 & 40 & 6 & $>15$ & 130 & 15 & 0 & 28 & 4 & 11 \\
\hline \multicolumn{10}{|l|}{ Subcluster 1C } \\
\hline N451: Rhodochrous strain & 31 & 1 & $>15$ & 18 & 4 & & 19 & 0 & \\
\hline \multicolumn{10}{|l|}{ Subcluster 1D } \\
\hline N420: Rhodochrous strain & 15 & 1 & & 20 & 1 & & 11 & 1 & \\
\hline N447: Rhodochrous strain & 17 & 2 & & 25 & 2 & & 19 & 1 & \\
\hline N454: Rhodochrous strain & 18 & 4 & & 65 & 2 & 6.5 & 17 & 1 & \\
\hline \multicolumn{10}{|l|}{ Subcluster $1 \mathrm{E}$} \\
\hline N324: Rhodochrous strain & 11 & 0 & & 13 & 1 & & 13 & 1 & \\
\hline N325: Rhodochrous strain & 11 & 1 & & 18 & 4 & & 14 & 1 & \\
\hline \multicolumn{10}{|l|}{ Subcluster $1 \mathrm{G}$} \\
\hline R35: Rhodochrous strain & 10 & 2 & & 12 & 2 & & 14 & 0 & \\
\hline R43: Rhodochrous strain & 26 & $<1$ & & 14 & 0 & & 27 & 1 & \\
\hline R46: Rhodochrous strain & 32 & 0 & $>15$ & 14 & 1 & & 116 & 12 & 0 \\
\hline N146: Rhodochrous strain & 21 & 1 & & 10 & 0 & & 11 & $<1$ & \\
\hline \multicolumn{10}{|l|}{ Subcluster $1 \mathrm{H}$} \\
\hline N11: Rhodochrous strain & 100 & & & 13 & 3 & & 20 & 2 & \\
\hline \multicolumn{10}{|l|}{ Subcluster 1I } \\
\hline N443: Rhodochrous strain & 11 & 1 & & 23 & 1 & & 19 & 1 & \\
\hline \multicolumn{10}{|l|}{ Subcluster $1 \mathrm{~J}$} \\
\hline N650: Rhodochous strain & 30 & 14 & & 27 & 3 & & 25 & 1 & 11 \\
\hline N651: Rhodochrous strain & 30 & 4 & & 26 & 2 & & 23 & 4 & \\
\hline N652: Rhodochrous strain & 25 & 4 & & 11 & 3 & & 43 & 2 & 9 \\
\hline N653: Rhodochrous strain & 24 & 7 & & 35 & 5 & 12 & 23 & 1 & \\
\hline \multicolumn{10}{|l|}{ Subgroup 14E } \\
\hline N124: Rhodochrous strain & 21 & 2 & & 20 & 2 & & 29 & 4 & \\
\hline \multicolumn{10}{|l|}{ Cluster 1} \\
\hline N13: Nocardia asteroides & 21 & 0 & & 16 & 0 & & 37 & 3 & 6 \\
\hline N668: $N$. asteroides & 17 & 2 & & 9 & 1 & & 100 & & \\
\hline N670: $N$. asteroides & 47 & 2 & & 14 & 2 & & 80 & 0 & 0 \\
\hline N671: $N$. asteroides & 34 & 7 & 13 & 11 & 1 & & 79 & 1 & 2 \\
\hline N672: $N$. asteroides & 27 & 5 & & 18 & 6 & & 92 & 1 & 1 \\
\hline N676: $N$. carnea & 29 & 1 & & 14 & 1 & & 35 & 0 & 4 \\
\hline N537: N. salmonicida & 44 & 4 & & 23 & 3 & & 45 & 1 & 9 \\
\hline
\end{tabular}


TABLE 2-Continued

\begin{tabular}{|c|c|c|c|c|c|c|c|c|c|}
\hline \multirow[b]{3}{*}{ DNA source } & \multicolumn{9}{|c|}{ Labelled DNA source } \\
\hline & \multicolumn{3}{|c|}{ Rhodochrous strain N11 } & \multicolumn{3}{|c|}{$\begin{array}{l}\text { Rhodochrous strain } \\
\text { N54 }\end{array}$} & \multicolumn{3}{|c|}{ Nocardia asteroides $\mathrm{N} 668$} \\
\hline & $\begin{array}{c}\text { Rela- } \\
\text { tive } \\
\text { DNA } \\
\text { bound } \\
(\%)\end{array}$ & $\begin{array}{l} \pm \text { Stan- } \\
\text { dard } \\
\text { error }\end{array}$ & $\begin{array}{c}\Delta T_{m(e)} \\
\left({ }^{\circ} \mathrm{C}\right)\end{array}$ & $\begin{array}{c}\text { Rela- } \\
\text { tive } \\
\text { DNA } \\
\text { bound } \\
(\%)\end{array}$ & $\begin{array}{c} \pm \\
\text { Stan- } \\
\text { dard } \\
\text { error }\end{array}$ & $\begin{array}{l}\Delta T_{m(e)} \\
\left({ }^{\circ} \mathrm{C}\right)\end{array}$ & $\begin{array}{c}\text { Rela- } \\
\text { tive } \\
\text { DNA } \\
\text { bound } \\
(\%)\end{array}$ & $\begin{array}{l} \pm \text { Stan- } \\
\text { dard } \\
\text { error }\end{array}$ & $\begin{array}{c}\Delta T_{m(e)} \\
\left({ }^{\circ} \mathrm{C}\right)\end{array}$ \\
\hline \multicolumn{10}{|l|}{ Cluster 2} \\
\hline N36: Nocardia caviae & $>100$ & 15 & 5.5 & 10 & 0 & & 32 & 1 & 5 \\
\hline N231: $N$. caviae & 61 & 3 & 6 & 6 & 0 & & 20 & 2 & \\
\hline N313: $N$. caviae & $>100$ & 15 & 0 & 10 & 1 & & 35 & 1 & 11 \\
\hline N563: N. caviae & $>100$ & 10 & 1 & 14 & 0 & & 34 & $<1$ & 9 \\
\hline \multicolumn{10}{|l|}{ Cluster 5} \\
\hline N318: Nocardia brasiliensis & 25 & 1 & & 10 & 1 & & 23 & 6 & \\
\hline \multicolumn{10}{|l|}{ Cluster 7} \\
\hline N306: Actinomadura madurae & 35 & 5 & $>15$ & 9 & 1 & & 28 & 1 & \\
\hline
\end{tabular}

a The extent of binding between DNA from test strains and labelled DNA from reference strains is expressed as a percentage relative to the extent of binding between labelled and unlabelled DNA from the reference strain itself. $\Delta T_{m(e),}$ a measure of the thermal stability of the DNA:DNA duplexes, was obtained by subtracting $T_{m(e)}$, the midpoint of thermal elution, of the molecular hybrids of the heterologous system from the $T_{m(e)}$ of the homologous hybrids. The ratio of labelled DNA was 1:15. The background, $\mathrm{imp} /$ minute per membrane, did not exceed 1 to $2 \%$ of the value in the homologous system. Specific activities of the DNA samples from the reference strains were (counts per minute per microgram): rhodochrous N11, 7,117 ; rhodochrous N54, 2,066; $N$. asteroides N668, 5,310.

erence system and the nocardiae (9 to $23 \%$ ) and the remaining rhodochrous strains (20 to $35 \%$ ) (Table 2).

With few exceptions the DNA preparations from the test strains showed a low degree of homology with the reference DNA from rhodochrous strain N11. The exceptions were the very high nucleotide sequence homologies found between this reference system and the DNA from the $N$. caviae strains. Apart from rhodochrous strain R46, a low degree of homology was found between DNA from the rhodochrous strains and reference DNA from $N$. asteroides N668. However, four of the five $N$. asteroides strains bound between 79 and $100 \%$ of the reference $N$. asteroides DNA (Table 2). The remaining strain, $N$. asteroides $\mathrm{N} 13$, bound $37 \%$ of the reference $N$. asteroides DNA; similar results were obtained between the latter and DNA from $N$. brasiliensis, $N$. carnea, $N$. caviae, $N$. salmonicida, and Actinomadura madurae.

The DNA reassociation rates of the reference strains are shown in Table 3.

\section{DISCUSSION}

The small degree of genetic relatedness between the $N$. asteroides reference system and the rhodochrous strains is in good agreement with earlier findings $(8,29)$. The DNA reassociation data, together with that from chemical,
TABLE 3. DNA:DNA reassociation rates of the reference strains ${ }^{a}$

\begin{tabular}{|c|c|c|c|c|c|c|}
\hline \multirow{3}{*}{ Code no. } & \multicolumn{6}{|c|}{ Reassociation rate } \\
\hline & \multicolumn{2}{|c|}{ N11 } & \multicolumn{2}{|c|}{ N54 } & \multicolumn{2}{|c|}{ N668 } \\
\hline & $\mathrm{N}$ & $\mathrm{H}$ & $\mathrm{N}$ & $\mathrm{H}$ & $\mathrm{N}$ & $\mathrm{H}$ \\
\hline $\begin{array}{r}\mathrm{N} 11 \\
\mathrm{H} \\
\mathrm{N}\end{array}$ & 100 & & 16 & 13 & 17 & 20 \\
\hline $\begin{array}{r}\mathrm{N} 54 \\
\mathrm{H} \\
\mathrm{N}\end{array}$ & & & 100 & & 17 & 18 \\
\hline $\begin{array}{c}\text { N668 } \\
\mathrm{H} \\
\mathrm{N}\end{array}$ & & & & & 100 & \\
\hline
\end{tabular}

${ }^{a} \mathrm{H}$, Labelled DNA; N, unlabelled DNA. The reassociation conditions are given in Table 2, footnote $a$.

numerical and serological studies $(2,17,32,39)$, support the view that the rhodochrous complex be considered a taxon equivalent to the genera Corynebacterium, Nocardia, and Mycobacterium $(5,14)$. The genus Gordona (37) was also equated with the genera Nocardia and Mycobacterium; however, the status of this taxon is not settled. We consider that the suggestion of classifying some rhodochrous strains in the ge- 
nus Gordona $(37,38)$ was premature. Recently, Gordona strains were classified in a rhodochrous phenon for which the earlier name $R$ hodococcus was proposed (Goodfellow and Alderson, in press).

There is much evidence indicating that $N$. asteroides forms a heterogeneous taxon whereas $N$. brasiliensis and $N$. caviae appear to be good taxospecies (34). Most of the data are derived from numerical taxonomic studies (16, 23,36 ), but additional evidence is provided by serological $(25,26)$, DNA reassociation $(7,10)$, phage typing (31), and phenetic $(4,20,33)$ studies.

Little is known about the properties of $N$. carnea and $N$. salmonicida, but the latter seems to be a distinct species (18). The small amount of genetic homology between the $N$. asteroides reference system and the representatives of $N$. brasiliensis, $N$. carnea, $N$. caviae, $N$. salmonicida, and $A$. madurae, and the recovery of $N$. asteroides as a genetically heterogeneous taxon, are in line with the earlier findings. Clearly more extensive numerical and nucleotide sequence homology analyses are required to determine the structure of the $N$. asteroides taxon.

It was very encouraging to find that the representatives of subcluster $1 \mathrm{~A}$ (Goodfellow and Alderson, in press) formed a DNA-homology group in which the strains shared $83 \%$ or more DNA with reference DNA from the type strain N54. These findings confirm our earlier study (29) and show that subcluster $1 \mathrm{~A}$ forms a taxon on the basis of genetic, numerical phenetic, chemical, and serological data $(2,17)$. However, the DNA base composition range (59 to $69 \mathrm{~mol} \% \mathrm{G}+\mathrm{C}$ ) of the constituent strains is wider than that reported for $N$. rubra (6).

Subcluster 1A and 1B strains share a high phenetic similarity (16; Goodfellow and Alderson, in press) and failure to classify them in a single taxon could be the result of test and sampling error. Since representatives of the two subclusters form a single homology group and contain similar mycolic acids (2), subcluster $1 \mathrm{~B}$ should be merged into subcluster $1 \mathrm{~A}$.

Subcluster $1 \mathrm{H}$ appears to be the same taxon as $N$. erythropolis (6). On the basis of DNA association, the latter was considered to be a homogeneous species (8-10). The only representative of subcluster $1 \mathrm{H}$ (Goodfellow and Alderson, in press), rhodochrous strain 11, showed little genetic homology with strains representing the other rhodochrous subclusters. In light of the numerical phenetic and earlier homology work, this is an encouraging result. However, additional representatives of subcluster $1 \mathrm{H}$ need to be examined to determine whether they share a high DNA homology with the rhodochrous N11 reference system.

It appears that at least five $(1 \mathrm{~A}, 1 \mathrm{C}, 1 \mathrm{D}, 1 \mathrm{G}$, and $1 \mathrm{H}$ ) of the rhodochrous subclusters (Goodfellow and Alderson, in press) are, or contain, genetically homogeneous taxa, and our studies are being extended to consider the remaining subclusters.

\section{REPRINT REQUESTS}

Address reprint requests to: Dr. M. Goodfellow, Department of Microbiology, The Medical School, The University, Newcastle upon Tyne NE1 7RU, U.K.

\section{LITERATURE CITED}

1. Adams, J. N., and G. H. Brownell. 1976. Genetic studies in Nocardia erythropolis, p. 285-309. In M. Goodfellow, G. H. Brownell, and J. A. Serrano (ed.), The biology of the nocardiae. Academic Press Inc., London.

2. Alshamaony, L., M. Goodfellow, and D. E. Minnikin. 1976. Free mycolic acids as criteria in the classification of Nocardia and the 'rhodochrous' complex. J. Gen. Microbiol. 92: 188-199.

3. Alshamaony, L., M. Goodfellow, D. E. Minnikin, and H. Mordarska. 1976. Free mycolic acids as criteria in the classification of Gordona and the 'rhodochrous' complex. J. Gen. Microbiol. 92:183-187.

4. Bend, D. 1973. Nocardia asteroides. A taxonomic study with clinical correlations. Am. Rev. Respir. Dis. 108:909-917.

5. Bousfield, I. J., and M. Goodfellow. 1976. The 'rhodochrous' complex and its relationships with allied taxa, p. 39-65. In M. Goodfellow, G. H. Brownell, and J. A. Serrano (ed.), The biology of the nocardiae. Academic Press Inc., London.

6. Bradley, S. G. 1971. Criteria for definition of Mycobacterium, Nocardia and the rhodochrous complex. Adv. Front. Plant Sci. 28:349-362.

7. Bradley, S. G. 1973. Relationships among mycobacteria and nocardiae based upon deoxyribonucleic acid reassociation. J. Bacteriol. 113:645-651.

8. Bradley, S. G., G. H. Brownell, and J. Clark. 1973. Genetic homologies among nocardiae and other actinomycetes. Can. J. Microbiol. 19: 1007-1014.

9. Bradley, S. G., and M. E. Huitron. 1973. Genetic homologies among nocardiae. Dev. Ind. Microbiol. 14:189-199.

10. Bradley, S. G., and M. Mordarski. 1976. Association of polydeoxyribonucleotides of deoxyribonucleic acids from nocardioform bacteria, p. 310-336. In M. Goodfellow, G. H. Brownell, and J. A. Serrano (ed.), The biology of the nocardiae. Academic Press Inc., London.

11. Bray, G. A. 1960. A simple efficient liquid scintillator for counting aqueous solutions in a liquid scintillation counter. Anal. Biochem. 1: 279-285.

12. Brenner, D. J. 1973. Deoxyribonucleic acid reassociation in the taxonomy of enteric bacteria. Int. J. Syst. Bacteriol. 23:298-307.

13. Colwell, R. R., R. Johnson, L. Wan, T. E. Lovelace, and D. J. Brenner. 1974. Numerical taxonomy and deoxyribonucleic acid reassociation in the taxonomy of some gram-negative fermentative bacteria. Int. J. Syst. Bacteriol. 24:422-433.

14. Cross, T., and M. Goodfellow. 1973. Taxonomy and classification of the actinomycetes, p. 11-121. In F. A. Skinner and G. Sykes (ed.), Actinomycetes: characteristics and practical importance. Academic Press Inc., London. 
15. Cross, T., and T. J. Rowbotham. 1974. The isolation enumeration and identification of nocardioform bacteria in clean and polluted streams and in lake waters and mud, p. 48-49. In G. H. Brownell (ed.), Proceed ings of the 1st International Conference on the Biology of Nocardiae, Merida, Venezuela. McGowen Printing Co., Augusta.

16. Goodfellow, M. 1971. Numerical taxonomy of some nocardioform bacteria. J. Gen. Microbiol. 69:33-80.

17. Goodfellow, M., A. Lind, H. Mordarska, S. Pattyn, and M. Tsukamura. 1974. A co-operative numerical analysis of cultures considered to belong to the 'rhodochrous' taxon. J. Gen. Microbiol. 85:291-302.

18. Gordon, R. E. 1974. Some bits and pieces of the genus Nocardia, p. 4-5. In G. H. Brownell (ed.), Proceedings of the 1st International Conference on the Biology of Nocardiae, Merida, Venezuela. McGrowen Printing Co., Augusta.

19. Gross, N. M., and L. G. Wayne. 1970. Nucleic acid homology in the genus Mycobacterium. J. Bacteriol. 104:630-634.

20. Holm, P. 1975. Seven cases of human nocardiosis caused by Nocardia farcinica. Sabouraudia 13:161169.

21. Huang, P. C., and E. Rosenberg. 1966. Determination of DNA base composition via depurination. Anal. Biochem. 16:107-113.

22. Jones, D. 1975. A numerical taxonomic study of coryneform and related bacteria. J. Gen. Microbiol. 87:5296.

23. Kurup, P. V., and J. A. Schmitt. 1973. Numerical taxonomy of Nocardia. Can. J. Microbiol. 19:1035-1048.

24. Lind, A., and M. Ridell. 1976. Serological relationships between Nocardia, Mycobacterium, Corynebacterium and the 'rhodochrous' taxon, p. 220-235. In M. Goodfellow, G. H. Brownell, and J. A. Serrano (ed.), The biology of the nocardiae. Academic Press Inc., London.

25. Magnusson, M. 1976. Sensitin tests as an aid in the taxonomy of Nocardia and its pathogenicity, p. 236265. In M. Goodfellow, G. H. Brownell, and J. A. Serrano (ed.), The biology of the nocardiae. Academic Press Inc., London.

26. Magnusson, M., and F. Mariat. 1968. Delineation of Nocardia farcinica by delayed type skin reactions on guinea pigs. J. Gen. Microbiol. 51:151-158.

27. Mordarska, M., M. Mordarski, and M. Goodfellow. 1972. Chemotaxonomic characters and classification of some nocardioform bacteria. J. Gen. Microbiol. 71:77-86.

28. Mordarskg, H., M. Mordarski, and D. Pietkiewicz. 1973. Chemical analysis of hydrolysates and cell extracts of Nocardia pellegrino. Int. J. Syst. Bacteriol. 23:274-277.

29. Mordarski, M., K. Szyba, G. Pulverer, and M. Goodfellow. 1976. Deoxyribonucleic acid reassociation in the classification of the 'rhodochrous' complex and allied taxa. J. Gen. Microbiol. 94:235-245.

30. Okanishi, M., and K. F. Gregory. 1970. Methods for the determination of deoxyribonucleic acid homologies in Streptomyces. J. Bacteriol. 104:1086-1094.

31. Pulverer, G., H. Schütt-Gerwitt, and K. P. Schaal. 1975. Bacteriophages of Nocardia asteroides. Med. Microbiol. Immunol. 161:113-122.

32. Ridell, M. 1974. Serological study of nocardiae and mycobacteria by using "Mycobacterium" pellegrino and Nocardia corallina precipitation reference systems. Int. J. Syst. Bacteriol. 24:64-72.

33. Schaal, K. P., and H. Heimerzheim. 1974. Mikrobiologische Diagnose und Therapie der Lungennocardiose. Mykosen 17:313-319

34. Sneath, P. H. A. 1976. An evaluation of numerical taxonomic techniques in the taxonomy of Nocardia and allied taxa, p. 74-101. In M. Goodfellow, G. H. Brownell, and J. A. Serrano (ed.), The biology of the nocardiae. Academic Press Inc., London.

35. Tacquet, A., M. T. Plancot, J. Debruyne, B. Devulder, M. Joseph, and J. Losfeld. 1971. Etudes préliminaries sur la classification numérique des mycobactéries et des nocardias. I. Relations taxonomiques entre $\mathbf{M y c o -}$ bacterium rhodochrous, Mycobacterium pellegrino et les genres Mycobacterium et Nocardia. Ann. Inst. Pasteur Lille 22:121-135.

36. Tsukamura, M. 1969. Numerical taxonomy of the genus Nocardia. J. Gen. Microbiol. 56:265-287.

37. Tsukamura, M. 1971. Proposal of a new genus, Gordona, for slightly acid-fast organisms occurring in sputa of patients with pulmonary disease and in soil J. Gen. Microbiol. 68:15-26.

38. Tsukamura, M. 1973. A taxonomic study of strains received as 'Mycobacterium' rhodochrous. Jpn. J. Microbiol. 17:189-197.

39. Tsukamura, M. 1975. Numerical analysis of the relationship between $M y$ cobacterium, rhodochrous group, and Nocardia by use of hypothetical median organisms. Int. J. Syst. Bacteriol. 25:329-335. 